\title{
Problems of the Desertification and Pasture Degradation in the Conditions of Azerbaijan
}

\author{
BH Aliyev, ZH Aliyev* and KM Babayeva \\ Institute of Soil Science and Agrochemistry of NAS of Azerbaijan, Azerbaijan
}

*Corresponding author: ZH Aliyev, Institute of Soil Science and Agrochemistry of NAS of Azerbaijan, Azerbaijan

\begin{abstract}
Studies have been conducted in the arid zone of Azerbaijan (Gobustan), where wind erosion is characteristic, which, together with environmental pollution, contributes to the expansion of greenhouse gases and leads to the degradation of pastures. Characterized by the process of sowing perennial legume grasses, improving the nutritional regime of the soil, activating nitrification, microbiological processes and preventing soil erosion. The "greenhouse effect" is a natural phenomenon in which certain gases in the lower atmosphere prevent some of the heat energy radiated from the Earth from escaping. The human-caused emissions of greenhouse gases (CO2, methane, nitrous oxide, and some industrial gases) have over the last few centuries added to this effect, making global temperatures warmer than they would otherwise be and affecting global weather patterns. The hole in the ozone layer is a separate phenomenon, but there are a few linkages with the greenhouse effect. For example, some gases which deplete ozone in the upper atmosphere (CFCs) also act as greenhouse gases in the lower atmosphere, and the trapping of heat in the lower atmosphere by the greenhouse effect leads to a cooler upper atmosphere and a slower recovery time for the ozone layer.
\end{abstract}

Keywords: Desertification; Wind Erosion; Pastures; Arid Climate; Global Warming; Perennial Grasses; Mineral Fertilizers

\section{Introduction}

The environmental problem is one of the main challenges facing civilization today. The factors associated with the problem of ecology are directed in two aspects: natural, man-made. The wrong attitude of a person to nature creates environmental instability: natural is precipitation, evaporation, air temperature, soil, wind, water and wind erosion, slope of the surface and vegetation, forest, natural water resources. Anthropogenic factors unsystematic use of pastures, industrial drilling, destruction of forests, expansion of industrial enterprises, environmental pollution. Today, environmental pollution is a problematic issue for humanity. It is known that the composition of atmospheric air contains a certain amount of natural gases: i.e. the composition of atmospheric air is stable and unchanged on the surface of the planet. In other words, in nature, absorption and equivalent evolution of gases constantly occur, which, as a result of the exchange between atmospheric layers, levels off and as a result, the same ratio of atmospheric compounds remains: nitrogen $78.08 \%$, oxygen $20.95 \%$, argon $0.94 \%$, carbon dioxide $0.03 \%$. However, the current ecological situation on the planet, creating a greenhouse effect, violates the natural layer of the atmosphere, i.e. there is an increase in nitric oxide, methane, carbon dioxide. The increase in carbon dioxide in the atmosphere becomes catastrophic. The disruption of the ecological balance on the globe today is of particular concern to scientists of the world and calls for a joint way to struggle to reduce and eliminate environmental pollution. With today's market relations, the development of agriculture to raise the economy of the republic and meet the needs of a growing population depends on the rational use of the soil. However, the environmental instability created by climate change is detrimental to agriculture [1]. Climatic anomalies damage the economy of the republic. Pollution of the environment, an increase in greenhouse gases contribute to the increase in temperature on Earth. The arid climate, the windy regime of the Absheron peninsula of Azerbaijan, where wind erosion is characteristic, is intensified by additional pollution of the soil cover. This involves the extraction of oil and gas, the chemical industry, the construction of residential neighborhoods, the use of fertilizers in agriculture, exhaust gases, etc. All these processes combine to create environmental barriers that lead to degradation 
of soil cover. On the other hand, a small amount of precipitation on Absheron contributes to aridization. This, of course, negatively affects the humus formation and soil fertility. These factors ultimately lead to the development of the process of desertification. It should be noted that the processes of degradation of dry lands have acquired global dimensions and approaches for their solution have been proposed comprehensively. This approach is enshrined in the International Convention to Combat Desertification (CCD), adopted by the international community in 1994. In the Azerbaijan Republic, this document was signed in 1997.

The problem of desertification in the republic has mainly areas of distribution also on the Absheron, Kura-Araks lowland and Nakhchivan Autonomous Republic. Studies show the influence of anthropogenic factors on desertification - felling, the reduction of the forest massif, the overload of pastures, i.e. abnormal livestock grazing, deflation and salinization processes. Irrational use of water resources, lowering the level of groundwater, intensive irrigation during the growing season, population density and urbanization. Natural factors in Azerbaijan are mainly characterized by complexity from a temperate to subtropical climate. Dry subtropical, moderately dry, semi-desert climate, etc. predominate. Along with this, global climate change is strongly felt in Azerbaijan, which sometimes manifests itself-unfavorable meteorological conditions (prolonged drought), changing relative and absolute humidity. The mechanism of the greenhouse effect is that the sun's rays, reaching the Earth, are absorbed by the soil surface, vegetation, water surface. The heated surfaces transfer thermal energy back into the atmosphere, but in the form of long-wave radiation. Atmospheric gases (oxygen, nitrogen, argon) do not absorb thermal radiation from the earth's surface but scatter it. However, as a result of burning of combustible minerals and other industrial processes in the atmosphere, carbon dioxide, carbon monoxide, various hydrocarbons-methane, ethane, propane, etc., accumulate, which do not dissipate but absorb thermal radiation coming from the Earth's surface. The screen arising in this way leads to the greenhouse effect - global warming. As a result of the above factors, it was found that from 1970 to 2000, desertification processes in Azerbaijan increased due to the increase in erosion processes, in which the range of fluctuation in different years changes from $36 \%$ to $43.3 \%$ (3,741,000 hectares) in Azerbaijan's conditions. Of these, 1,520.6 thousand hectares (17.6\%) are moderately eroded, an average of 881.3 thousand hectares (10.2\%), a high degree of 1339.2 thousand hectares (15.5\%) which led to desertification [2].

As is known, soil moisture plays a crucial role in the development of both ground and underground power for growing crops. Soil moisture creates optimal conditions for the dissolution and assimilation of mineral and organic compounds by plants. Therefore, in any studies should pay attention to the amount of moisture under crops. The purpose of the research is to study the development of the process of desertification and to develop measures to combat the reduction of their consequences on the example of Gobustan.

The Kyoto Protocol does not require emission reductions from the developing countries, some of which like China and India produce significant amounts of $\mathrm{CO}_{2}$. This is one of the arguments that has been used by the USA to support its withdrawal from the Protocol. On a per capita basis, the developing countries produce only a fraction of the $\mathrm{CO}_{2}$ that developed countries do, but this is predicted to change over time as they seek to improve their standard of living and their populations increase. The developing countries argue that the developed countries have grown rich exploiting fossil fuels and creating the majority of greenhouse gas emissions, and thus should take the lead in cutting emissions now without seeking to impose equal responsibilities on the rest of the world without equal economic rights. Developed countries have taken the lead under the terms of the Berlin mandate in 1995 and by accepting legally binding targets under the Kyoto Protocol. The Clean Development Mechanism and the new Expert Group on Technology Transfer under the Kyoto Protocol are designed to help transfer "clean technology" to developing countries so that they can begin to disengage their economies from reliance on fossil fuels, but this is only on a project-by-project basis [3].

\section{Materials and Method}

Studies were conducted in Gobustan district on eroded graybrown (chestnut) soils. Field experiments laid by the method of B.A. Dospekhova in 3 replicates. The natural greenhouse effect acts to trap some of the sun's warmth from escaping back into space and makes life possible on Earth. It is caused by the natural compounds of water vapor, carbon dioxide, methane, and nitrous oxide. Without the greenhouse effect, the Earth would be about $30^{\circ} \mathrm{C}$ colder. In the last two centuries human activity has "enhanced" 1 this natural effect by adding significantly higher levels of carbon dioxide (31\% increase), methane (up 151\%), and nitrous oxide (up 17\%), as well as some artificial compounds which also act as greenhouse gases (per fluorocarbons, hydro fluorocarbons, sculpture hexafluoride, and the ozone depleting gases) [4]. When solar radiation enters the atmosphere, visible light passes through and ultraviolet light is absorbed by the ozone layer. The visible light absorbed by the Earth is converted to heat energy, which is radiated outwards. While most gases allow heat to pass through to the upper atmosphere, the greenhouse gases absorb this heat energy and re-radiate it rather than let it escape. The hole in the ozone layer is a separate phenomenon, but there are a few linkages with the greenhouse effect. Studies were conducted on Gobustan winter pastures on eroded gray-brown (chestnut) soils.

As can be seen from Table 1 in the test version with natural grass stand, field moisture averaged $10.4 \%$ in spring, however, under crops of legumes and mixed crops, the field soil moisture content slightly increases and in mixed crops with mineral 
fertilizers reaches 17.2 and 16, 9\% moisture. The data of Tables 2-4 illustrate the features of the nitrogen regime of the soils of the studied winter pastures. Ammonia nitrogen absorbed by the soilabsorbing complex in the control with natural herbage in May is
$36.49 \mathrm{mg} / \mathrm{kg}$ of soil $\left(28.4+8.09\right.$ ) (absorbed + water-soluble $\mathrm{NO}_{3}$ ), nitrate $\mathrm{N}-\mathrm{NO}_{3} 2.1 \mathrm{mg} / \mathrm{kg}$ of soil. However, under crops of alfalfa, the crop is $43.1 \mathrm{mg} / \mathrm{kg}$ of soil, i.e. $32.9+10.2 \mathrm{mg} / \mathrm{kg}$, nitrate form $3.8 \mathrm{mg} / \mathrm{kg}$ of soil.

Table 1: Impact of legume-cereal grasses and mineral fertilizers on field humidity of ordinary gray-brown (chestnut) winter pasture soils.

\begin{tabular}{|c|c|c|c|c|c|c|}
\hline No & Experience versions & Depth, cm & $\begin{array}{l}\text { Average for 2003-2005 } \\
\text { in } \%\end{array}$ & Depth, cm & $\begin{array}{l}\text { Average for } 2003- \\
2005 \text { in } \%\end{array}$ & Depth, cm \\
\hline 1 & Natural control. Herbage & $0-30$ & 10.4 & 11.9 & 11.5 & 11.2 \\
\hline 2 & Alfalfa sown & $0-30$ & 15.6 & 15.1 & 13.4 & 14.7 \\
\hline 3 & Transcaucasian Esparcet & $0-30$ & 15.5 & 14.7 & 14.3 & 14.8 \\
\hline 4 & Pasture ryegrass & $0-30$ & 15.9 & 14.8 & 14.5 & 15.1 \\
\hline 5 & Meadow fescue & $0-30$ & 16.1 & 14.8 & 14.8 & 15.2 \\
\hline 6 & Ryegrass + Lucerne + Meadow Fescue & $0-30$ & 16.5 & 15.7 & 14.6 & 15.6 \\
\hline 7 & Esparcet + Ryegrass + Meadow Fescue & $0-30$ & 16.7 & 15.7 & 15.0 & 15.8 \\
\hline 8 & Alfalfa + Mixed sowing $\mathrm{N}_{30} \mathrm{P}_{30} \mathrm{~K}_{30}$ & $0-30$ & 17.2 & 16.4 & 15.6 & 16.4 \\
\hline 9 & Esparcet + Mixed seeding $\mathrm{N}_{30} \mathrm{P}_{30} \mathrm{~K}_{30}$ & $0-30$ & 16.9 & 16.4 & 15.7 & 16.4 \\
\hline
\end{tabular}

Table 2: Influence of legume-cereal grasses and mineral fertilizers on the content of ammonia and nitrate nitrogen of gray-brown (chestnut) soils of winter pastures (2003).

\begin{tabular}{|c|c|c|c|c|c|c|c|c|c|}
\hline \multirow[b]{2}{*}{$\begin{array}{l}\text { Experience } \\
\text { Options }\end{array}$} & \multirow[b]{2}{*}{$\begin{array}{l}\text { Depth in } \\
\text { cm. }\end{array}$} & \multicolumn{3}{|c|}{ May } & \multirow{2}{*}{$\begin{array}{c}\text { June } \\
\text { Are } \\
\text { swallowed } \\
\text { up } \mathrm{NH}_{3} \\
\end{array}$} & \multicolumn{4}{|c|}{ July } \\
\hline & & $\begin{array}{c}\text { Are } \\
\text { swallowed } \\
\text { up } \mathrm{NH}_{3} \\
\end{array}$ & $\begin{array}{c}\text { Water } \\
\text { management } \\
\text { Rome } \mathrm{NH}_{3}\end{array}$ & $\begin{array}{c}\text { Nitrates } \\
\mathrm{N}-\mathrm{NO}_{3}\end{array}$ & & $\begin{array}{c}\text { Water } \\
\text { management } \\
\text { Rome } \mathrm{NH}_{3}\end{array}$ & $\begin{array}{l}\text { Nitrates } \\
\mathrm{N}-\mathrm{NO}_{3} \\
\end{array}$ & $\begin{array}{c}\text { Are } \\
\text { swallowed } \\
\text { up } \mathrm{NH}_{3} \\
\end{array}$ & $\begin{array}{c}\text { Water } \\
\text { management } \\
\text { Rome } \mathrm{NH}_{3}\end{array}$ \\
\hline 1 & $0-30$ & 28.4 & 8.09 & 2.1 & 26.2 & 7.5 & 2.5 & 22.3 & 4.6 \\
\hline 2 & $0-30$ & 32.9 & 10.2 & 3.8 & 29.7 & 7.6 & 3.5 & 24.7 & 5.4 \\
\hline 3 & $0-30$ & 35.0 & 12.7 & 4.8 & 32.5 & 10.6 & 3.9 & 30.6 & 6.3 \\
\hline 4 & $0-30$ & 34.9 & 9.40 & 3.9 & 31.9 & 11.2 & 4.1 & 28.5 & 5.9 \\
\hline 5 & $0-30$ & 35.0 & 9.40 & 4.0 & 30.8 & 10.9 & 4.5 & 25.9 & 5.2 \\
\hline 6 & $0-30$ & 34.0 & 10.3 & 4.6 & 33.5 & 11.7 & 3.0 & 27.7 & 6.5 \\
\hline 7 & $0-30$ & 36.0 & 9.80 & 3.65 & 34.7 & 8.5 & 2.9 & 29.9 & 5.3 \\
\hline 8 & $0-30$ & 39.2 & 10.3 & 4.05 & 33.8 & 8.11 & 4.2 & 30.2 & 5.7 \\
\hline 9 & $0-30$ & 38.2 & 11.2 & 4.8 & 35.3 & 12.3 & 3.9 & 31.3 & 6.1 \\
\hline
\end{tabular}

From Table 2 it can be seen that under the herbs both ammonium and nitrate forms of nitrogen increase in May, which indicates an increased activity of the soil microflora. In early spring, active ammonification with the onset of favorable conditions (establishing the optimum air temperature) goes into nitrification, the content of nitrate nitrogen in May slightly increases, but in June there is a slight decrease in ammonia nitrogen and an increase in nitrate [5]. As noted above, the greatest amount of ammonia nitrogen found in the soil in spring is associated with the enhancement of inaccessible organic nitrogen compounds to the available mineral occurs with the help of microorganisms. Under the influence of enzymes of bacteria, actinomycetes, nitrogen-containing organic substances decompose to amino acids and further to ammonia. This process occurs at optimum humidity and temperature. Under aerobic conditions, ammonium salts are oxidized to nitrates. It is established that the samples taken during the summer period in June of 2003. differ in somewhat lower content of ammonia and nitrate nitrogen. It should be noted that in early spring, the soil contains mainly ammonium nitrogen, which originated and is fixed in the soil by the soil-absorbing complex. With the onset of favorable conditions, that is, the presence of moisture, heat and oxygen, ammonia nitrogen passes into nitrate. However, the accumulated nitrates are carried away with the crop (Tables 2-4) in July there is a noticeable decrease in nitrates and ammonia nitrogen. In this season, with the change 
in hydrothermal conditions, microbiological processes, including enzymatic ones, are damped, the nitrification process is suspended. In the fall, with the precipitation of ammonia, the ammonification and nitrification processes are renewed again, as a result of which a significant number of nitrates appear in the soil, and the ammonia content increases.

Table 3: Influence of legume-cereal grasses and mineral fertilizers on the content of ammonia and nitrate nitrogen of gray-brown (chestnut) soils of winter pastures (2004).

\begin{tabular}{|c|c|c|c|c|c|c|c|c|c|}
\hline \multirow[b]{2}{*}{$\begin{array}{c}\text { Experience } \\
\text { Options }\end{array}$} & \multirow[b]{2}{*}{$\begin{array}{l}\text { Depth in } \\
\text { cm. }\end{array}$} & \multicolumn{3}{|c|}{ May } & \multicolumn{3}{|c|}{ June } & \multicolumn{2}{|c|}{ July } \\
\hline & & $\begin{array}{c}\text { Are } \\
\text { swallowed } \\
\text { up } \mathrm{NH}_{3} \\
\end{array}$ & $\begin{array}{c}\text { Water } \\
\text { management } \\
\text { Rome } \mathrm{NH}_{3}\end{array}$ & $\begin{array}{c}\text { Nitrates } \\
\mathrm{N}-\mathrm{NO}_{3}\end{array}$ & $\begin{array}{c}\text { Are } \\
\text { swallowed } \\
\text { up } \mathrm{NH}_{3} \\
\end{array}$ & $\begin{array}{c}\text { Water } \\
\text { management } \\
\text { Rome } \mathrm{NH}_{3}\end{array}$ & $\begin{array}{c}\text { Nitrates } \\
\mathrm{N}^{-\mathrm{NO}_{3}} \\
\end{array}$ & $\begin{array}{c}\text { Are } \\
\text { swallowed } \\
\text { up } \mathrm{NH}_{3} \\
\end{array}$ & $\begin{array}{c}\text { Water } \\
\text { management } \\
\text { Rome } \mathrm{NH}_{3}\end{array}$ \\
\hline 1 & $0-30$ & 28.5 & 8.10 & 2.0 & 27.3 & 7.0 & 2.3 & 23.4 & 5.1 \\
\hline 2 & $0-30$ & 33.1 & 9.25 & 3.7 & 29.9 & 7.3 & 2.7 & 25.6 & 5.6 \\
\hline 3 & $0-30$ & 34.7 & 11.51 & 4.9 & 31.7 & 7.4 & 2.6 & 24.8 & 5.4 \\
\hline 4 & $0-30$ & 34.9 & 10.6 & 4.7 & 31.9 & 7.4 & 2.5 & 25.7 & 5.5 \\
\hline 5 & $0-30$ & 35.4 & 10.8 & 4.3 & 33.6 & 7.6 & 2.6 & 25.6 & 5.3 \\
\hline 6 & $0-30$ & 35.7 & 11.2 & 4.6 & 33.4 & 7.5 & 2.4 & 26.1 & 5.7 \\
\hline 7 & $0-30$ & 35.9 & 11.0 & 4.5 & 32.7 & 7.8 & 2.7 & 25.9 & 5.6 \\
\hline 8 & $0-30$ & 36.9 & 12.2 & 5.9 & 33.9 & 7.8 & 2.9 & 26.3 & 5.8 \\
\hline 9 & $0-30$ & 36.6 & 12.0 & 5.4 & 33.7 & 7.9 & 2.8 & 26.6 & 5.7 \\
\hline
\end{tabular}

Table 4: Influence of legume-cereal grasses and mineral fertilizers on the content of ammonia and nitrate nitrogen of gray-brown (chestnut) soils of winter pastures (2005).

\begin{tabular}{|c|c|c|c|c|c|c|c|c|c|c|}
\hline \multirow{2}{*}{$\begin{array}{c}\text { Experience } \\
\text { Options }\end{array}$} & \multirow{2}{*}{$\begin{array}{c}\text { Depth in } \\
\text { cm. }\end{array}$} & \multicolumn{3}{|c|}{ May } & \multicolumn{2}{|c|}{ June } & \multicolumn{4}{|c|}{ July } \\
\hline & & $\begin{array}{c}\text { Are } \\
\text { swallowed } \\
\text { up } \mathrm{NH}_{3} \\
\end{array}$ & $\begin{array}{c}\text { Water } \\
\text { management } \\
\text { Rome } \mathrm{NH}_{3}\end{array}$ & $\begin{array}{c}\text { Nitrates } \\
\mathrm{N}^{-\mathrm{NO}_{3}}\end{array}$ & $\begin{array}{c}\text { Are } \\
\text { swallowed } \\
\text { up } \mathrm{NH}_{3} \\
\end{array}$ & $\begin{array}{c}\text { Water } \\
\text { management } \\
\text { Rome } \mathrm{NH}_{3}\end{array}$ & $\begin{array}{c}\text { Nitrates } \\
\mathrm{N}-\mathrm{NO}_{3}\end{array}$ & $\begin{array}{c}\text { Are } \\
\text { swallowed } \\
\text { up } \mathrm{NH}_{3} \\
\end{array}$ & $\begin{array}{c}\text { Water } \\
\text { management } \\
\text { Rome } \mathrm{NH}_{3}\end{array}$ & $\begin{array}{c}\text { Nitrates } \\
\mathrm{N}-\mathrm{NO}_{3}\end{array}$ \\
\hline 1 & $0-30$ & 28.9 & 8.5 & 2.3 & 28.5 & 7.7 & 2.1 & 24.7 & 4.9 & \\
\hline 2 & $0-30$ & 35.7 & 9.6 & 3.9 & 24.7 & 8.4 & 2.5 & 27.5 & 5.4 & \\
\hline 3 & $0-30$ & 35.9 & 10.1 & 3.9 & 32.8 & 7.9 & 2.6 & 25.3 & 5.2 & \\
\hline 4 & $0-30$ & 36.1 & 10.4 & 4.0 & 33.5 & 7.7 & 2.5 & 26.1 & 5.1 & \\
\hline 5 & $0-30$ & 36.4 & 10.6 & 4.0 & 34.9 & 7.8 & 2.6 & 25.9 & 5.0 & \\
\hline 6 & $0-30$ & 36.9 & 11.3 & 4.4 & 35.3 & 7.8 & 2.5 & 26.4 & 5.2 & \\
\hline 7 & $0-30$ & 37.2 & 11.9 & 4.5 & 34.8 & 7.7 & 2.6 & 26.2 & 5.0 & \\
\hline 8 & $0-30$ & 38.2 & 12.7 & 5.2 & 36.2 & 7.4 & 2.5 & 27.6 & 5.5 & \\
\hline 9 & $0-30$ & 37.9 & 12.4 & 5.0 & 36.0 & 7.5 & 2.6 & 26.9 & 5.4 & \\
\hline
\end{tabular}

From the above, it should be concluded that in the arid zone of Azerbaijan, in the Gobustan arid region, where wind erosion prevails, winter pasture productivity decreases sharply. This process combined with environmental pollution, i.e. with increasing greenhouse gases, progressive global warming leads to desertification of the territory. Nevertheless, the sowing of perennial leguminous herbs with the use of optimal norms of mineral fertilizers increases the organic mass of the soil, activates the biochemical processes in the soil, which leads to an increase in the biopotential of eroded soils and prevent the process of desertification [6].

\section{Results and Discussion}

The experiments conducted on eroded ordinary gray-brown (chestnut) soils of winter pastures in Gobustan under crops and grasses with the use of mineral fertilizers in mixed crops had a positive effect on the soil nutrition pattern. As noted above, the arid climate of the region, combined with environmental pollution and anthropogenic influences, including non-compliance with the rate of livestock grazing, leads to the degradation of pastures and desertification of the territory. However, the sowing of perennial grasses, especially of legume-grass grass mixture with 
the application of mineral fertilizers, had a positive effect on the nutritional regime of the studied soils.

The application of mineral fertilizers for sowing perennial herbs enhances the microbiological conditions, namely, improves the nitrification processes associated with the assimilation of nitrogen nutrition, the improvement of the nutritional regime of the soil positively responds to the vital activity of the perennial herbs, which in turn replenishes the soil with organic material and restores fertility, which is considered as method of combating pasture erosion and desertification.

\section{Conclusion}

Greenhouse gas emissions have been calculated in two ways. Firstly, estimates have been made at a national level based on emissions from whole sectors (e.g., agriculture, food and drink manufacturing) and other top-level sources. Greenhouse gas emissions data has been taken from a variety of sources to derive an overview of the impact of food and drink across a range of sectors from agriculture to households and waste management. The emissions associated with food have been allocated to the final quantity that is consumed by UK households, net of exports and food and drink that is sold via the hospitality/catering sector. The factors therefore account for waste along the supply chain associated with the production of food for household consumption, although they exclude emissions from managing this waste. Secondly, as part of this chapter, individual carbon factors for different products have been identified. The available tables center on unprocessed (fruit, vegetables, raw meat) rather than processed foods (e.g., ready meals, sauces, prepared sandwiches, carbonated drinks) and do not cover all food products wasted. These are significant gaps and mean that the sum of the tables outlined herein will not add up to the average of all foods.

\section{References}

1. Aliyev BG, Babaeva KM (2003) Factors associated with the development of the process of desertification. magazine "Agrarian Science" Azerb (13): 161-164.

2. Aliev BG, Babaeva KM (2007) Development of a model of the process of desertification of the Absheron Peninsula, railway Agrarian science, Azerbaijan (1-3): 163-165.

3. Geokchay Sh Yu (2018) Fundamentals of geographical ecology. Textbook "Ecoprint", pp. 407.

4. Salaev ME (1966) Soils of the Lesser Caucasus. Anz SSR (Eds); Baku, Azerbaijan.

5. Aliyev BG, Aliyev IN (2001) Technique and technology of drip irrigation in Azerbaijan. Baku. Zia - Nurlan Baku, Azerbaijan.

6. Rao S Radha krishna (1968) Linear statistical methods. Fizmatgiz.
(C) (i) This work is licensed under Creative

To Submit Your Article Click Here: Submit Article
DOI: $10.32474 /$ OAJESS.2019.02.000134

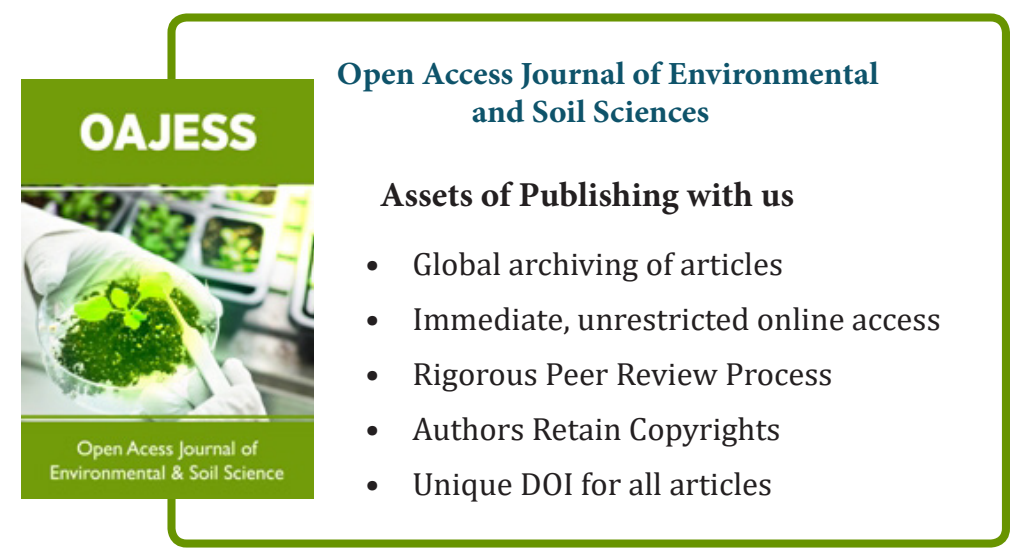

